\title{
PENGARUH MODEL PROBLEM BASED LEARNING BERBANTU MIND MAP TERHADAP HASIL BELAJAR SISWA PADA MATERI POKOK FLUIDA DINAMIK
}

\author{
Roby Saputra Harapan Sitindaon*) dan Makmur Sirait**) \\ roby.harapan@yahoo.co.id \\ *)Alumni Pendidikan Fisika Universitas Negeri Medan \\ **) Dosen Jurusan Fisika Universitas Negeri Medan
}

\begin{abstract}
ABSTRAK
Penelitian ini bertujuan untuk mengetahui pengaruh penerapan model problem based learning (PBL) berbantu mind map terhadap hasil belajar siswa pada materi pokok fluida dinamik di kelas XI semester II SMA Negeri 5 Medan T.P. 2014/2015. Jenis penelitian ini adalah quasi eksperimen dengan desain penelitian control group pretest - postest. Populasi seluruh siswa kelas XI SMA Negeri 5 Medan terdiri dari 6 kelas. Sampel penelitian diambil 2 kelas yang ditentukan dengan teknik cluster random sampling yaitu kelas XI-MIA 2 sebagai kelas eksperimen dan kelas XI-MIA 3 sebagai kelas kontrol dengan jumlah siswa masing-masing 27 orang. Instrumen yang digunakan untuk mengumpulkan data adalah tes uraian untuk soal pretes dan postes dan lembar observasi aktivitas belajar siswa. Uji hipotesis menggunakan uji Wilcoxon. Berdasarkan uji Wilcoxon didapat ada pengaruh yang signifikan model problem based learning (PBL) berbantu mind map terhadap hasil belajar siswa pada materi pokok fluida dinamik.
\end{abstract}

Kata Kunci : problem based learning, mind map, hasil belajar, aktivitas.

\begin{abstract}
This study aimed to determine the effect of problem based learning (PBL) model assisted on concept mind map on physics learning outcomes of student in the subject matter dynamic fluid for XI class SMA Negeri 5 Medan T.P. 2014/2015. This research is a quasi experimental study design with control group pretestposttest. Population of all students in grade class XI SMA Negeri 5 Medan consisting of 6 classes. Samples were taken 2 classes are determined by random cluster sampling technique that is class XI-MIA 2 as the experimental class and class XI-MIA 3 as the control class with the student amount of each 27 student. The instrument used to collect the data is in the form of essay test for pretest and posttest questions and student activity sheets observation. To test the hypothesis used Wilcoxon test. According to the Wilcoxon test there is the influence of problem based learning (PBL) model assisted on concept mind map on physics learning outcomes of student in the subject matter dynamic fluid.
\end{abstract}

Keywords: problem based learning, mind map, learning outcomes, activities 


\section{PENDAHULUAN}

Manusia merupakan mahluk yang tidak bisa dipisahkan dari pendidikan. Struktur manusia dan situasi di dunia membuat proses belajar mengajar tidak terhindarkan. Dari semua tindakan yang dilakukan manusia, orang pasti akan berharap bahwa mengajar adalah tindakan yang dilakukan dengan pemikiran yang paling mendalam dan dengan pengertian yang paling jelas akan sasaran-sasarannya. Namun ternyata pengharapan ini sangat salah arah sebab sejumlah besar guru hanya sekedar mengajar, mengajar sebagaimana mereka dulu di ajar, menerapkan kebiasaan yang sudah mendarah daging tanpa direnungkan, tanpa memutuskan apa yang akan diajarkan dan apa yang akan ditekankan. Jelas tidak dapat disangkal bahwa hal ini tidak dapat dibenarkan dan tidak bertanggung jawab (Wolterstorff, 2014).

Fisika sebagai salah satu cabang ilmu pengetahuan alam (IPA) merupakan suatu ilmu pengetahuan yang mempelajari bagian-bagian dari alam dan interaksi didalamnya serta dapat diterangkan dengan menggunakan konsep-konsep sederhana. Aplikasi dari fisika dan ilmu pengetahuan lainnya telah menghasilkan teknologi yang telah memudahkan dan membantu manusia. Johnson (2014) mengatakan, "teknologi abad ke-20 memungkinkan para ilmuwan melakukan pengamatan dengan tingkat ketepatan yang tinggi dan terperinci terhadap galaksi dan atom, planet dan partikel-partikel sub-atom, mikroorganisme, dan sel-sel otak."

Fisika merupakan mata pelajaran yang lebih banyak memerlukan pemahaman daripada penghafalan. Namun kenyataannya fisika sering dipandang sebagai suatu ilmu abstrak oleh siswa dengan teori, rumus-rumus, dan soal-soal yang sulit. Sulitnya pelajaran fisika juga lebih didominasi karena kecenderungan proses belajar mengajar dikelas berlangsung secara klasikal dengan metode pengajaran yang menitikberatkan proses menghafal daripada pemahaman konsep. Guru biasanya kurang dapat menjelaskan fisika itu dengan contoh-contoh yang sederhana, menarik dan mudah dimengerti para siswa dan aplikasinya dalam kehidupan sehari-hari. Padahal menurut Tim Pengembangan Ilmu Pendidikan FIP-UPI (2007), pembelajaran fisika akan lebih bermakna apabila dampak dari pembelajaran fisika siswa dapat mengembangkan pengalaman untuk lebih memahamai dunia nyata.

Berdasarkan observasi yang telah dilakukan peneliti dengan menyebarkan angket kepada siswa di SMA Negeri 5 Medan, dari 39 siswa hanya 1 orang yang menyukai mata pelajaran fisika. Fisika sulit dan membosankan adalah salah satu alasan mengapa hal ini bisa terjadi, cara guru mengajar fisika juga menjadi salah satu penyebabnya. Hasil wawancara peneliti dengan salah satu guru mata pelajaran fisika di sekolah ini mengakui bahwa metode ceramah adalah metode yang paling sering digunakan guru tersebut untuk mengajarkan fisika.

Melibatkan siswa secara aktif dalam pembelajaran merupakan tuntutan dasar dalam pembelajaran fisika sehingga dibutuhkan model pembelajaran yang menjangkau lebih jauh diluar pendekatan-pendekatan yang berpusat pada guru, untuk menantang siswa dengan aspek belajar aktif, mendukung 
keterampilan berpikir tingkat tinggi dan keterampilan belajar mandiri. Alternatif model pembelajaran yang dapat mengakomodasi hal tersebut salah satunya adalah model problem based learning (PBL).

Jacobsen, dkk., (2009) mengatakan "mode PBL adalah model pembelajaran yang memanfaatkan masalah sebagai focal point untuk keperluan investigasi dan penelitian siswa." Pelajaran dimulai dengan mengangkat suatu permasalahan atau pertanyaan sebagai bahan investigasi dan penelitian siswa, dimana siswa bertanggung jawab untuk memecahkannya dengan bantuan dari guru. Arends (2008) menyatakan bahwa model PBL adalah model pembelajaran dimana guru menyodorkan berbagai masalah, memberikan pertanyaan, dan memfasilitasi investigasi dan dialog. Situasi bermasalah yang membingungkan atau tidak jelas akan membangkitkan rasa ingin tahu siswa sehingga membuat mereka tertarik untuk menyelidiki, dalam hal ini akan membangkitkan rasa ingin tahu siswa untuk mempelajari fisika itu sendiri. Tan (2009) mengatakan bahwa "masalah dapat menimbulkan rasa ingin tahu, penyelidikan dan pemikiran yang dalam, sehingga masalah dapat digunakan untuk memicu pembelajaran dan sebagai kendaraan untuk menumbuhkan kreativitas."

Teori belajar yang melandasi model PBL adalah teori belajar kontruktivisme. Tokoh dalam teori kontruktivisme adalah Jhon Dewey, Jean Piaget dan Lev Vygotsky. Menurut Arends (2008) PBL tidak dirancang untuk membantu guru menyampaikan informasi dengan jumlah besar kepada siswa, tetapi dirancang terutama untuk membantu siswa mengembangkan keterampilan berpikir, keterampilan menyelesaikan masalah, keterampilan intelektualnya; mempelajari peran-peran orang dewasa dengan mengalaminya melalui berbagai situasi rill atau situasi yang disimulasikan dan menjadi pelajar yang otonom. Lingkungan belajar model PBL adalah siswa dituntut untuk aktif selama proses pembelajaran berlangsung, dimana guru mengupayakan lingkungan kelas tempat pertukaran ide-ide yang terbuka dan jujur dapat terjadi.

Penelitian yang terkait tentang model PBL telah dilakukan oleh Sihotang (2014) pada kelas eksperimen hasil pretes adalah 43,81 dan hasil postes adalah 80,05. Pemaparan hasil penelitian di atas menunjukan bahwa ada pengaruh yang signifikan model PBL terhadap hasil belajar siswa. Kelemahan dalam penelitian ini adalah pengelolaan kelas pada saat diskusi berlangsung dan tidak menggunakan media, jadi dalam penelitian ini akan menggunakan media yaitu mind map. Penggunaan media mind map dapat membuat siswa melihat hubungan antara satu ide dengan ide lainnya dalam materi ajar dengan tetap memahami konteksnya dan memusatkan perhatian siswa sehingga siswa tetap fokus dalam proses pembelajaran. Mind map dikembangkan oleh Tony Buzan, seorang kepala brain foundation.

Penelitian bertujuan untuk mengetahui pengaruh model PBL berbantu mind map terhadap hasil belajar siswa pada materi pokok fluida dinamik di kelas XI SMA Negeri 5 Medan T.P 2014/2015. Penelitian ini juga bertujuan untuk 
mengetahui aktivitas siswa selama proses pembelajaran dengan menggunakan model pembelajaran model PBL berbantu mind map.

\section{METODE PENELITIAN}

Penelitian ini dilaksanakan di SMA Negeri 5 Medan dengan populasi seluruh siswa kelas XI terdiri dari 6 kelas. Teknik pengambilan sampel dilakukan dengan cara teknik sampel kelas acak (cluster random sampling). Sampel penelitian terdiri dari dua kelas yang mewakili populasi dengan mempunyai karakteristik yang sama. Kelas XI-MIA 2 menggunakan model PBL dan XI-MIA 3 menggunakan pembelajaran konvensional dengan jumlah siswa masing-masing 27 orang.

Rancangan penelitian ini quasi eksperiment dengan desain: control group pretest - postest. Pretes diberikan kepada kelas eksperimen dan kelas kontrol untuk mengetahui kemampuan awal siswa pada kedua kelas, kemudian diberikan perlakuan yang berbeda, kelas eksperimen dengan model PBL berbantu mind map dan kelas kontrol dengan pembelajaran konvensional. Setelah perlakuan, diberikan postes untuk kelas eksperimen dan kelas kontrol untuk mengetahui hasil belajar kognitf siswa.

Alat pengumpul data dalam penelitian ini adalah tes hasil belajar berbentuk uraian. Tes hasil belajar ini digunakan untuk mengetahui kemampuan siswa pada tingkat kognitif dan observasi untuk mengetahui aktivitas belajar siswa. Adapun spesifikasi tes hasil belajar siswa pada materi pokok fluida dinamik sebanyak 8 butir tes yang tersusun mulai dari $\mathrm{C}_{4}, \mathrm{C}_{5}$, dan $\mathrm{C}_{6}$. Alasan pemilihan kategori tes hasil belajar dimulai dari $\mathrm{C}_{4}, \mathrm{C}_{5}$, dan $\mathrm{C}_{6}$ karena seperti yang dikatakan Arends (2008) "bahwa model PBL adalah model yang mendukung pemikiran tingkat tinggi dalam situasi berorientasi masalah."

Uji Wilcoxon digunakan untuk menguji hipotesis karena data pretes dan postes berdistribusi tidak normal. Prosedur uji peringkat bertanda Wilcoxon sebagai berikut: pertama-tama memberi nomor urut untuk setiap harga mutlak selisih $\left(\mathrm{X}_{\mathrm{i}^{-}}\right.$ $\mathrm{Y}_{\mathrm{i}}$ ). Harga mutlak terkecil diberi nomor urut atau peringkat 1, harga mutlak selisih berikutnya diberi nomor urut 2 dan harga mutlak terbesar diberi nomor urut n. Jika terdapat selisih yang harga mutlaknya sama besar, untuk nomor urut diambil rata-ratanya. Untuk tiap nomor urut diberikan juga tanda yang didapat dari selisih (X-Y), selanjutnya menghitung jumlah nomor urut yang bertanda positif dan juga jumlah nomor urut yang bertanda negatif. Setelah itu diambil jumlah yang harga mutlaknya paling kecil. Jumlah inilah yang dipakai untuk menguji hipotesis.

\section{HASIL DAN PEMBAHASAN}

Adapun hasil penelitian ini adalah bahwa nilai rata-rata pretes kelas eksperimen sebesar 14,96 dan nilai rata-rata pretes kelas kontrol sebesar 16,07. Sedangkan setelah diberikan perlakuan yang berbeda dimana pada kelas eksperimen diberikan pembelajaran dengan model PBL berbantu mind map dan pada kelas kontrol diberikan pembelajaran konvensional, diperoleh bahwa rata-rata postes kelas eksperimen sebesar 45,93 dan rata-rata postes kelas kontrol sebesar 29,30. Dari hasil ini dapat disimpulkan bahwa ada pengaruh 
penerapan model PBL berbantu mind map terhadap hasil belajar siswa pada materi pokok fluida dinamik di kelas XI semester II SMA Negeri 5 Medan. Nilai pretes kelas eksperimen dan kelas kontrol ditunjukkan pada Gambar 1 sedangkan nilai postes pada kelas eksperimen dan kelas kontrol ditunjukkan pad Gambar 2.

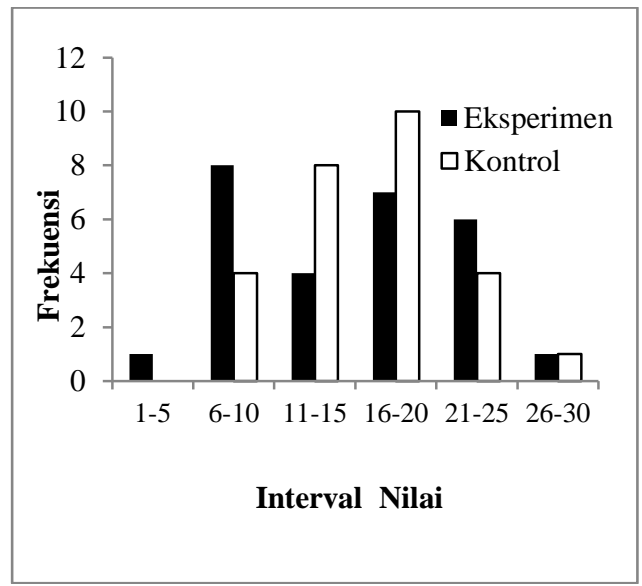

Gambar 1. Nilai Pretes Kelas Eksperimen dan Kelas Kontrol

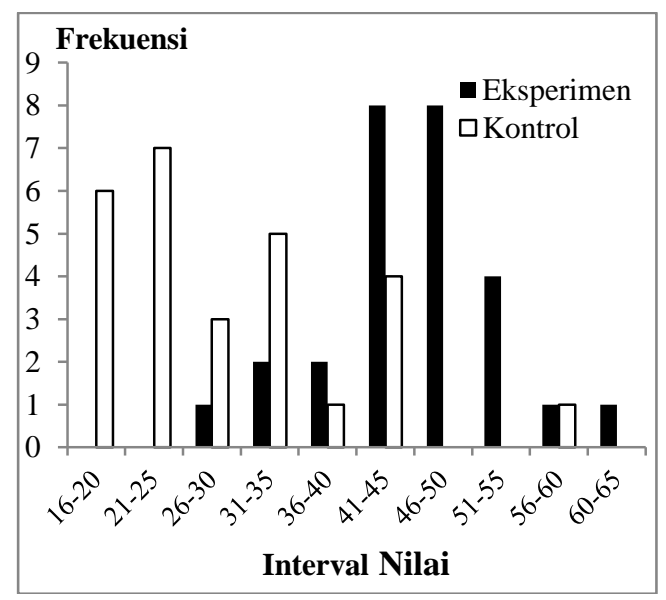

\section{Gambar 2. Nilai Postes Kelas Eksperimen dan Kelas Kontrol}

Selama proses pembelajaran dilakukan pengamatan aktivitas siswa. Observasi aktivitas ini hanya dilakukan di kelas eksperimen yang sesuai dengan pengembangan model pembelajaran yang digunakan yaitu model PBL. Kelas kontrol yang menggunakan pembelajaran konvensional, dalam penelitian ini tidak dilakukan pengamatan aktivitas siswa.

Hasil penelitian ini menunjukkan bahwa ada pengaruh penerapan model PBL berbantu mind map terhadap hasil belajar siswa pada materi pokok fluida dinamik di kelas XI semester II SMA Negeri 5 Medan. Hasil belajar siswa yang diajarkan dengan menerapkan model PBL berbantu mind map lebih baik dibandingkan dengan siswa yang diajarkan dengan pembelajaran konvensional. Perolehan nilai ratarata pretes siswa di kelas kontrol sebesar 16,07 dan nilai rata-rata postes sebesar 29,30 sedangkan di kelas eksperimen diperoleh nilai ratarata pretes sebesar 14,96 dan nilai rata-rata postes sebesar 45,93. Pengaruh model PBL terhadap hasil belajar siswa pada aspek kognitf karena model PBL mempunyai tiga konsep utama. Pertama, keterampilan penyelidikan dan keterampilan mengatasi masalah sehingga pengetahuan yang didapat siswa berasal dari penyelidikan autentik yang berupa masalah. Kedua, perilaku dan keterampilan sosial sesuai peran orang dewasa, dalam hal ini siswa dapat mengembangkan kemampuan untuk menyimpulkan dari penyelidikan yang telah dilakukan. Ketiga, keterampilan untuk belajar secara mandiri dimana siswa dalam proses pembelajaran dituntut untuk aktif dalam menganalisis unsur-unsur yang diperlukan, melaksanakan percobaan dan mempresentasikan hasil karya untuk menjawab permasalahan yang telah diberikan di awal proses pembelajaran. Model PBL dalam 
penelitian ini juga didukung dengan penggunaan media mind map. Media mind map juga memberikan perbedaan hasil belajar siswa pada kelas eksperimen dan kelas kontrol. Penggunaan media mind map dapat membuat siswa melihat hubungan antara satu ide dengan ide lainnya dalam materi ajar dengan tetap memahami konteksnya dan memusatkan perhatian siswa sehingga siswa tetap fokus dalam proses pembelajaran sehingga dengan bantuan mind map siswa dapat lebih mudah untuk melakukan analisis dalam memecahkan masalah. Hal ini didukung oleh Buzan (2009), mengatakan: "Peta pikiran merupakan cara paling mudah untuk memasukkan informasi dari otak, cara ini adalah cara yang kreatif dan efektif dalam membuat catatan, sehingga boleh dikatakan peta pikiran benar-benar memetakan pikiran, menggunakan garis, lambang, kata-kata, serta gambar, berdasarkan seperangkat aturan yang sederhana, mendasar, alami, dan akrab bagi otak." Mind map bekerja seperti cara kerja otak, saat otak menerima suatu informasi, otak akan berusaha menghubungkan dengan informasi lainnya yang sudah ada sebelumnya.

Arends (2008) menyatakan "esensi PBL berupa menyuguhkan berbagai situasi bermasalah yang autentik dan bermakna kepada siswa, yang dapat berfungsi sebagai batu loncatan untuk investigasi dan penyelidikan." Situasi bermasalah yang membingungkan atau tidak jelas akan membangkitkan rasa ingin tahu siswa sehingga membuat mereka tertarik dan antusias untuk melakukan penyelidikan pada percobaan yang akan dilakukan. Teori kontruktivisme yang menjadi dasar dari model PBL menyatakan bahwa pembelajaran bukan hanya sekedar proses menyerap informasi, gagasan, dan keterampilan tetapi dalam sebuah pembelajaran siswa membangun pengetahuannya secara aktif melalui proses personal maupun sosial. Konsekuensi teori kontruktivisme mengharuskan dalam proses pembelajaran yang menerapkan model PBL siswa melakukan penyelidikan autentik untuk mencari penyelesaian nyata terhadap masalah yang autentik. Setelah masalah diberikan kepada siswa maka siswa secara aktif harus menganalisis dan mendefenisikan masalah tersebut, mengembangkan hipotesis, mengumpulkan dan melakukan dan menganalisa informasi, melakukan eksperimen (jika diperlukan), membuat inferensi, dan merumuskan kesimpulan.

Berdasarkan hasil penelitian yang dilakukan oleh Sihotang (2014) diperoleh bahwa ada perbedaan hasil belajar siswa antara kelas yang menggunakan model PBL dan pembelajaran konvensional. Oleh karena itu, model PBL lebih baik dari pembelajaran konvensional, dimana pemahaman konsep siswa yang dibelajarkan dengan model PBL lebih baik dibandingkan siswa yang dibelajarkan dengan pembelajaran konvensional. Fokus pembelajaran dalam model PBL adalah pada masalah yang dipilih sehingga siswa tidak hanya mempelajari konsep-konsep yang berhubungan dengan masalah tetapi juga memahami konsep yang relevan dengan masalah yang menjadi pusat perhatian dan memperoleh pengalaman belajar yang berhubungan dengan keterampilan menerapkan metode ilmiah dalam 
pemecahan masalah dan menumbuhkan pola pikir yang kritis.

Model PBL memiliki kelebihan yang salah satunya meningkatkan aktivitas pembelajaran siswa. Hasil dari penelitian ini menunjukkan adanya peningkatan aktivitas siswa di kelas eksperimen yang menerapkan model PBL berbantu mind map, aktivitas belajar siswa di kelas eksperimen setiap pertemuan meningkat. Perhitungan menggunakan uji N-gain untuk mengetahui peningkatan aktivitas siswa. Pada kelas eksperimen yang menggunakan model PBL berbantu mind map dengan persentase $\mathrm{N}$-gain aktivitas untuk pertemuan I dan II = 18,22 dengan kategori rendah dan persentase $\mathrm{N}$-Gain aktivitas untuk pertemuan II dan III $=33,90$ dengan kategori sedang.

Investigasi autentik dan kolaborasi dalam model PBL dapat meningkatkan aktivitas pembelajaran siswa. Kolaborasi, dalam hal ini PBL ditandai oleh siswa-siswa yang bekerja sama dengan siswa lain dalam bentuk berpasang-pasangan atau kelompok untuk menginvestigasi masalah kehidupan nyata yang membingungkan. Aktivitas siswa adalah keterlibatan siswa dalam bentuk sikap, pikiran, perhatian, dan aktivitas dalam kegiatan pembelajaran untuk menunjang keberhasilan proses belajar mengajar dan memperoleh manfaat dari kegiatan tersebut. Peningkatan aktivitas siswa yaitu meningkatnya jumlah siswa yang terlibat aktif belajar, meningkatnya jumlah siswa yang berpartisipasi dalam pelaksanaan kegiatan diskusi kelompok maupun diskusi kelas, meningkatnya jumlah siswa yang menyelesaikan masalah yang autentik, dan meningkatnya keterampilan dalam mempresentasikan hasil karya.

Penilaian sikap siswa pada kelas eksperimen juga meningkat setiap pertemuan. Rata-rata persentase penilaian sikap kelas eksperimen dengan menggunakan model PBL berbantu mind map adalah 64,28 yang termasuk dalam kategori baik. Penilaian keterampilan siswa untuk setiap pertemuan juga mengalami peningkatan. Rata-rata persentase penilaian keterampilan kelas eksperimen dengan menggunakan model PBL berbantu mind map adalah 69,14 yang termasuk dalam kategori cukup baik. Penggunaan model PBL berbantu mind map dapat meningkatkan hasil belajar dan aktivitas siswa, tetapi selama pembelajaran masih ada kendala yang dihadapi yaitu waktu yang tersedia tidak cukup untuk melaksanakan semua fase pada model PBL khususnya dalam melakukan percobaan, presentasi hasil karya dari setiap kelompok yang membutuhkan waktu yang banyak sehingga waktu untuk peneliti menganalisis dan mengevaluasi proses pembelajaran sangat singkat mengakibatkan ada bagian-bagian materi yang tidak sempat diajarkan. Kendala lainnya adalah mengorganisasi siswa dalam bentuk kelompok dan membimbing siswa dalam melakukan percobaan dan diskusi karena tidak melibatkan observer. Selain itu, situasi yang kurang kondusif pada saat pembelajaran sehingga tujuan pembelajaran tidak berlangsung sesuai dengan yang diharapakan. 
KESIMPULAN DAN SARAN

\section{Kesimpulan}

Ada pengaruh yang

signifikan model PBL berbantu mind map terhadap hasil belajar siswa pada materi pokok fluida dinamik di kelas XI Semester II SMA Negeri 5 Medan T.P 2014/2015. Aktivitas siswa selama mengikuti proses pembelajaran dengan menggunakan model PBL berbantu mind map pada materi pokok Fluida Dinamik di kelas XI semester II SMA Negeri 5 Medan T.P 2014/2015 diperoleh rata-rata aktivitas siswa sebesar 71,28 termasuk dalam kategori cukup aktif.

\section{Saran}

Peneliti selanjutnya diharapkan memilih sekolah yang waktu untuk satu pertemuan pada mata pelajaran fisika yaitu $3 \times 45$ menit sehingga dapat melaksanakan setiap fase-fase dalam model PBL khususnya dalam melakukan percobaan, presentasi hasil karya dari setiap kelompok yang membutuhkan waktu yang banyak sehingga fase dimana peneliti menganalisis dan mengevaluasi proses pembelajaran dapat dilaksanakan. Peneliti selanjutnya diharapakan lebih mengoptimalkan pengelolaan kelas khususnya pada saat melakukan percobaan dan melakukan diskusi berlangsung agar tidak terjadi kegaduhan di dalam kelas, misalnya dengan menggunakan media selain media mind map yang dapat membantu peneliti dalam melakukan pengelolaan kelas. Peneliti selanjutnya juga diharapkan dapat membuat masalah yang lebih menarik dan nyata yang terjadi dalam kehidupan sehari-hari sehingga masalah tersebut sekaligus dapat menjadi motivasi untuk siswa sehingga siswa antusias dalam mengikuti proses pembelajaran dan mengurangi kegaduhan di dalam kelas.

\section{DAFTAR PUSTAKA}

Arends, R. I., (2008), Learning To Teach: Belajar untuk Mengajar Buku Dua, Pustaka Pelajar, Yogyakarta

Buzan, T., (2009), Buku Pintar Mind Mip, Gramedia Pustaka Utama, Jakarta

Jacobsen, D. A., Eggen, P., Kauchak, D., (2009) Methods for Teaching: $\quad$ Metode-metode Pengajaran Meningkatkan Belajar Siswa TK-SMA, Pustaka Pelajar, Yogyakarta

Johnson, E. B., (2014), Contextual Teaching \& Learning, Kaifa, Bandung

Sihotang, P.S. 2014. Pengaruh Model Problem Based Learning Terhadap Hasil Belajar Siswa Pada Materi Kalor Di Kelas X Semester II SMA Negeri 02 Pematang Siantar T.P 2013/2014. Skripsi, FMIPA, Unimed, Medan.

Tan, O-S., (2009), Problem Based Learning and Creativity, Cengange Learning Asia Pte Ltd, Singapore

Tim Pengembangan Ilmu Pendidikan FIP-UPI, 2007, Ilmu \& Aplikasi Pendidikan, PT Imperial Bhakti Utama, Bandung

Wolterstorff, N. P., (2014) Mendidik Untuk Kehidupan: Refleksi Mengenai Pengajaran dan Pembelajaran Kristen, Momentum, Jakarta. 
